\title{
External Debt and Economic Growth Nexus in the Ecowas: A Threshold Analysis
}

\author{
Abu Bakarr Tarawalie ${ }^{1, ~ *, ~ T a l a t u ~ J a l l o h ~}{ }^{2}$ \\ ${ }^{1}$ Department of Economics and Commerce, Fourah Bay College, University of Sierra Leone, Freetown, Sierra Leone \\ ${ }^{2}$ Department of Economics, University of Ghana, Accra, Ghana
}

Email address:

tarawalieabu@yahoo.com (A. B. Tarawalie)

${ }^{*}$ Corresponding author

To cite this article:

Abu Bakarr Tarawalie, Talatu Jalloh. External Debt and Economic Growth Nexus in the Ecowas: A Threshold Analysis. International Journal of Business and Economics Research. Vol. 10, No. 5, 2021, pp. 178-186. doi: 10.11648/j.ijber.20211005.13

Received: September 22, 2021; Accepted: October 8, 2021; Published: October 15, 2021

\begin{abstract}
Literature on the debt-growth nexus postulates that external debt is viewed as capital that closes the financing gap, boost investment and promote growth. Against this background, and given the low revenue mobilization drive, the ECOWAS Member States resort to external borrowing with a view to complement domestic revenue and enhance their ability to finance large infrastructural projects and boost economic growth. However, external debt accumulation has not translated into high growth in the ECOWAS Member States. Thus, the paper investigates the impact of external debt on economic growth in the ECOWAS countries, and determines the optimal threshold level of external debt that promotes growth. The study utilizes panel data for 15 countries spanning from 2000 to 2019, and employs four estimation techniques including the Pooled Ordinary Least Squares (POLS), Fixed Effect Model (FEM), Random Effect Model (REM) and Panel Corrected Standard Errors (PCSE) techniques. The empirical results suggest that external debt (ED), Openness to trade (Opn) and Control of Corruption (CoC) are the main determinants of economic growth in the ECOWAS countries. Specifically, openness has a positive effect on growth, while both external debt and control of corruption have negative impact on growth. Furthermore, the study reveals evidence of a nonlinear relationship between external debt and real GDP, and confirms that the optimal threshold level of external debt in the ECOWAS countries is $111 \%$. Intuitively, the result indicates that any increase in external debt above $111 \%$ will reduce growth in the ECOWAS countries by $0.0001 \%$ while below the threshold level, economic growth will improve by $0.0222 \%$. The policy implication is that, governments of the ECOWAS countries should ensure that, external debt are utilized in growth enhancing sectors, with a view to boost growth. Also, governments should develop debt management strategic policies, with a view to keep debt levels within sustainable limits.
\end{abstract}

Keywords: ECOWAS Countries, External Debt, Economic Growth, Panel Data Analysis

\section{Introduction}

The issue of external debt and its impact on economic growth and development remains a major concern for most developing countries, which are typified with low level of domestic resource mobilization, low savings, low per capital income, large fiscal deficit, rising current account imbalances and high savingsinvestment gap. Such situations constraint developing economies to raise adequate resources required to promote investment and boost economic growth. In order to fill the resource gap, most developing countries resort to external borrowing with a view to complement domestic savings and enhance their ability to undertake productive activities.
Furthermore, countries engage in external borrowing to finance current account deficits arising from external imbalances, in order to strengthen their external reserve positions. Thus, sustainable growth is considered a major concern for developing economies that are epitomized with burgeoning fiscal deficits triggered by profound current account deficit and large debt service, including external debt servicing, Reinhart et al. [1].

The theoretical literature has produced different opinion on the debt-growth nexus. Proponents of the Harrod-Domar school posits that, a rise in the level of savings leads to capital accumulation, which in turn is an essential ingredient for growth. Thus, external borrowing is viewed as capital that seeks to close the financing gap, hence to boost growth, Eaton [2]. Thus, the 
literature posits that, external borrowing is desirable to enhance growth via capital accumulation and productivity growth, especially when such resources are channeled towards growth enhancing sectors, including agriculture, education, health, manufacturing etc. Furthermore, the argument for external borrowing emanates from the belief that domestic borrowing will crowd out private sector investment and create financial instability, Panizza et al. [3]. Meanwhile, the literature suggests that large external borrowing coupled with good governance and strong institutions will improve the efficiency of capital and boost economic growth. Also, external debt can promote investment and growth up to a given threshold, thereafter further external debt accumulation will have a negative impact on growth. However, others argued that, high debt servicing obligations associated with external borrowing will create distortions in the allocation of resources, dampens investment and growth, Krugman [4]. The literature has identified four channels through which external debt could have a negative impact on growth. These channels include: the debt overhang hypothesis, crowding-out; liquidity constrain and factor productivity hypotheses. Pattillo et al [5]. The empirical literature has produced mixed results regarding the external debt-growth nexus. On the one hand, some researchers have established a positive relationship between debt and growth, Jayaraman et al [6]. However, others have confirmed an inverse relationship between debt and growth, Butts [7]. Furthermore, some researchers find no relationship between these two variables, Frimpong and Oteng-Abaye [8].

The Economic Community of West African States (ECOWAS), is a regional Bloc comprising of 15-memer states (see Table 6). ECOWAS was established on the $28^{\text {th }}$ May, 1975, with the mandate of promoting economic integration amongst the constituting countries. In pursuit of economic integration in the ECOWAS region, the Bloc is aspiring to launch a common currency, the Eco, akin to the Euro within the European Union. One of the convergence criteria that must be satisfied by all member states is the attainment of debt/GDP ratio of not more than 70 percent. Achievement of this criterion remains a daunting challenge for most of the countries, owing to their quest to solicit external funding for financing infrastructural projects, given the low domestic resource mobilization drive coupled with the huge savings-investment gap that characterized most of these countries. The large external borrowing (from both commercial and concessionary source) by most members of the ECOWAS has not translated to significant increase in output growth or address the huge infrastructural deficit. The heavy reliance on external borrowing has led to increase debt accumulation and debt servicing, which tends to exacerbate macroeconomic disturbances in the respective countries and also hurt future generations.

Figure 1 presents trend analysis of real GDP growth and external debt for the ECOWAS region. Real GDP growth exhibits a rising trend between 2000-2002, consistent with higher external debt. Although external debt witnessed a declining trend between 2003-2008, it however remained above the 70 percent threshold, as countries relied on external borrowing for financing infrastructural project in order to accelerate growth. The declining trend in the external debt during this period was attributed to the notion that many ECOWAS countries subscribed to debt relief under the highly indebted poor countries (HIPC) initiative. Growth pattern also shows that, real GDP growth decelerated between 2003-2007, due to structural and institutional setbacks as well as policy slippages. However, growth peaked up between 2007-2013, with an average growth rate of 6.9 percent, largely due to the paradigm shift in the region's trading pattern towards fast-growing economies including China and India, coupled with the improved macroeconomic fundamentals and reforms. However, during this period, external debt remained below the 70 percent threshold, triggered by strong growth and increased export earnings. Real GDP growth however, plummeted between 2014-2016, due to significant drop in the price of raw material globally, especially oil, decline in oil production in Nigeria (the largest economy in ECOWAS) and the Ebola outbreak. This period also witnessed a build-up of external debt as countries seek for external financing, given the low domestic revenue mobilization drive. Growth however, rebounded between 2017-2019, as a result of a surge in commodity prices, coupled with the containment of the Ebola. However, during this period, the region witnessed an increase in external debt and debt servicing.

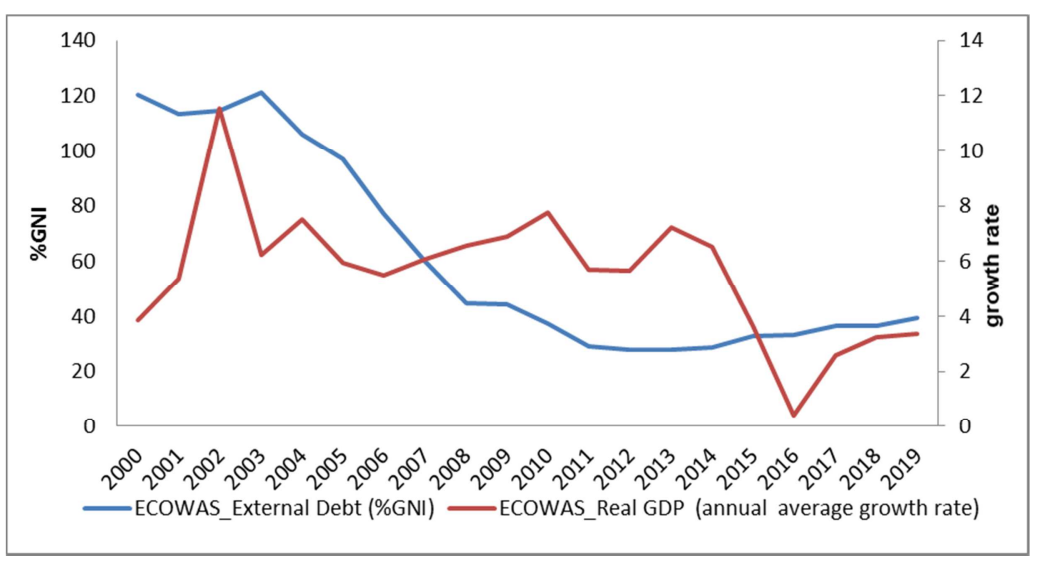

Source: WDI (2021) and UNCTAD Stats (2021)

Figure 1. Trends in External Debt and Real GDP for ECOWAS. 
It is worth mentioning that, external debt accumulation is not a bad policy measure, but rather the effective utilization of such resources that actually matters. The questions for most policy analysists are the following: how effective are these external funding utilized? Are the resources utilized for productive investment in growth enhancing sectors, or are they used for final consumption? What level of external debt will propel growth? What motivate an economy to contract external debt? This study seeks to provide answers to the aforementioned questions. Thus, the main objective of this study, is to investigate the impact of external debt on economic growth in the ECOWAS Member States, and to determine the threshold level of external debt conducive for growth. The study contributes to the debt-growth literature using data for 15-countries spanning from 2000 to 2019. The study employs recent panel estimation technique to examine the external debt-growth nexus, and also tests for the presence of nonlinearities in the debt-growth nexus. Specifically, study utilizes the Pooled Ordinary Least Squares (POLS), Fixed Effect Model (FEM), Random Effect Model (REM) and Panel Corrected Standard Errors (PCSE) techniques. The rest of the paper is structured as follows: Section two presents a survey of the theoretical and empirical literature, while section three articulates the methodology. Section four analyzes the empirical findings, and section five presents the conclusion and proffer policy recommendations.

\section{Literature Review}

The theoretical literature on the debt-growth nexus is premised on the following concepts: the Harrod-Domar model, debt overhang hypothesis, crowding-out effect, liquidity constraint hypothesis and factor productivity growth compression hypothesis. The Harrod-Domar model postulates that capital accumulation in the form of savings is crucial for economic growth. The model suggests that, external borrow is used to close the financing gap with a view to boost growth. The Harrod-Dormar model justifies that the fundamental trigger of economic growth is investment or capital accumulation which is determined by savings. Proponents of the debt overhang doctrine defined debt overhang as a condition where in the expected repayment on foreign debt falls short of the contractual value of the debt. Thus, debt overhang theory posits that, if investors expect a situation of high inflation, persistent devaluation and broad macroeconomic imbalances and distortions, then there is disincentive to invest, which may impact negatively on growth. Furthermore, proponents of debt overhang opine that, investment will decline if investors expect a rise in the tax rate on returns to capital for debt servicing. The crowding-out school of thought suggests that, heavy debt service burden on government may crowd-out public spending on key sectors of the economy including education and health, which are vital for economic growth. Furthermore, huge debt burden will require the government to utilize short term revenue for debt servicing, hence crowding-out public investment to growth enhancing sectors of the economy, Serieux and Yiagadeesen [9]. The liquidity constraint hypothesis indicates that, a country with a high debt burden require large inflow of foreign currency to serve its debt. However, in a situation where a country's export earnings, capital inflows and foreign reserve position remain slow, then such a country will have a daunting challenge in servicing its debt. Thus, the country may be required to pursue the devaluation of its currency with a view to boost net export and attracts foreign exchange inflows. Advocates of the factor productivity theory postulates that, in a situation of high debt burden and uncertainty, there is tendency for investment to be skewed towards short term instrument to the disadvantage of long-term instrument. Thus, investors will be discouraged from investing in long term projects owing to high level of uncertainty surrounding long term projects. Furthermore, the literature suggests that, if external debt is insignificant in the savings and investment function, it can still have an effect on output growth via its impact on factor productivity and investment mix.

The Empirical literature has produced mixed results regarding the debt-growth nexus. Some researchers found a positive impact of external debt on growth. See Warner [10] and Baum et al [11]. Other studies established a negative relationship between External debt and growth. Leading scholars in this domain include Shahor [12], De Vita et al. [13], Geiger [14], Cordella et al. [15] and Deshpane [16]. Yet, a few studies have found no relationship between debt and growth, examples include Chowdhury [17], Afxentiou and Serletis [18], Cohen [19]. Furthermore, regarding threshold analysis, Minea and Parent [20] found that debt had a negative impact on growth when the debt-to-GDP ratio is above 90 percent and below 115 percent. However, they found a positive relationship, when debt surpasses 115 percent.

Jarju et al [21] analyzed trends and investigated the relationship between external debt and economic growth in the WAMZ, using a reduced form growth model and panel data for the period 2000 to 2014. The result showed that external debt has a positive impact on growth. Also, Amoateng and Amoako-Adu [22] examined the relationship between external debt servicing, economic growth and exports for thirty-five African countries from 1971-199. Utilizing both time series and cross-sectional data, the result indicated that debt had a positive effect on economic growth.

Senadza et al [23] examined the impact of debt on growth for 39 Sub-Saharan Africa (SSA) countries. The study used annual data from 1990 to 2013. Employing the Generalized Methods of Moments (GMM) approach, the findings showed that external debt had a negative impact on growth. Utilizing data for SSA from 1980 to 1990, Fosu [24] investigated the impact of external debt on growth, and the study established a negative relationship between debt and growth, that is, debt had a dampening impact on economic growth. In a related study, Iyoha [25] also examined the effect of external debt on economic growth in SSA using a small macro econometric model and simulation approach spanning from 1970 to 1994. 
The findings revealed that, debt had a negative effect on growth. Cunningham [26] examined the effect of debt burden on economic growth for 16 heavily indebted nations, using panel data 1971-1987. The findings showed that debt had a negative effect on growth. Ezeabasili et al [27] investigated the impact of external debt on economic in Nigeria during 1975 and 2006. The result indicated that external debt was harmful to economic growth. Similarly, using Nigeria data from 1970 to 2007, Ogunmuyiwa, M. S. [28] examined the effect of external debt on growth. Using the Johanson framework, the study found weak relationship between debt and growth. Also, Ajayi and Oke [29] investigated the impact of the external debt on growth in Nigeria. The study applied the OLS regression approach, and the findings showed that external debt was harmful to growth. Karagöl [30] examined the impact of external debt on growth in Turkey from 1956-1996. Using a multivariate co-integration technique, the findings revealed that, external debt was negatively related with growth. Were [31] investigated the effect of external debt on economic growth and private investments, in Kenya using times series data from 1970 to 1995 . The findings revealed that external debt negatively impacted growth. Malik et al [32] examined the impact of external debt on growth in Pakistan for from 1972- 2005. The result revealed a negative relationship between external debt and economic growth.

In terms of threshold effect, N'Zue [33] conducted a study to establish the relationship between external debt and economic growth in the ECOWAS region. Using panel CS-ARDL estimation approach, with data from 1990 to 2016, study showed that external debt had a positive effect on economic performance up to a threshold level of debt of $45 \%$ in the short run, and a threshold of $42.52 \%$ in the long run. Also, Elbadawi et al. [34] examined the impact of external debt on growth for 99 developing countries, using a quadratic model with fixed and random effects estimations. The result showed debt impacted negatively on growth beyond a threshold level of $97 \%$. Medina et al [35] examined the effect of public debt on growth in Mexico with data from 1994 and 2016. The result showed that external debt was harmful to economic growth, and a threshold level in debt-to-GDP ratio of $27 \%$.

Despite the plethora of studies on the debt-growth nexus, studies on the ECOWAS region are limited in scope. Thus, this study adds to the debt-growth literature using data for 15-countries spanning from 2000 to 2019, and employing recent panel estimation techniques including; the Pooled Ordinary Least Squares (POLS), Fixed Effect Model (FEM), Random Effect Model (REM) and Panel Corrected Standard Errors (PCSE) techniques.

\section{Methodology}

To analyze the impact of external debt on economic growth and establish the threshold level of external debt, the study utilized a panel data for 15 ECOWAS countries for 20 years period spanning from 2000 to 2019 .

Given that the dimension of our panel data set is such that $\mathrm{T}>\mathrm{N}$, i.e. unbalanced panel, and based on the structure of
ECOWAS countries as well as theoretical underpinning, the empirical model for the study is specified as follows:

$$
\begin{gathered}
\text { RealGDP } i t=\alpha_{0}+\alpha_{1} E D_{i t}+\alpha_{2} O p n_{i t}+\alpha_{3} I n f_{i t}+ \\
\alpha_{4} \operatorname{CoC}_{i t}+\alpha_{5} P S_{i t}+v_{i t}
\end{gathered}
$$

Where: RealGDP $P_{i t}$ is Real Gross Domestic Product for country $i$ at time $t$, this variable is used to measure economic growth. $E D_{i t}$ is External Debt for country $i$ at time $t$, and it is the independent variable of interest. Furthermore, Opn, Inf, $C o C$ and $P S$ are the control variables, representing trade openness, inflation, control of corruption and political stability, respectively; $\alpha_{0}$ is the intercept while $\alpha_{i}(i=1,2, \ldots, 5)$, are the parameters to be estimated. However, $v_{i t}=\mu_{i}+\varepsilon_{i t}$ where $\mu_{i}$ denotes the time invariant unobservable country-specific effect and $\varepsilon_{i t}$, the disturbance term that is identically and independently distributed. The choice of control variables is largely influenced by the literature and related studies, see Topal, [36]; Ahlborn and Schweickert, [37]. The study expects $\alpha_{1}$ and $\alpha_{3}<0$, while $\alpha_{2}, \alpha_{4}$ and $\alpha_{5}>0$.

The study employed the static panel estimation techniques in its analysis. To produce a robust estimation results, the study utilized four estimation techniques, including the Pooled Ordinary Least Squares (POLS), Fixed Effect Model (FEM), Random Effect Model (REM) and Panel Corrected Standard Errors (PCSE) techniques, respectively. The POLS is an estimation technique that relies on the least square approach, wherein, the observations are pooled across time and cross-section unit. However, it ignores the possibility of individual unobserved effect. Unlike the POSL, the FEM controls for time-invariant unobserved characteristics which are allowed to be correlated, arbitrarily, with the explanatory variables across time (ibid). The FEM is, however, inconsistent if the explanatory variables are uncorrelated with the unobserved time-invariant effect. In this case, the REM is more consistent. The REM, a feasible Generalized Least Square (GLS) estimator, assumes that there is no correlation between the unobserved effect and the explanatory variable over time. In the event that the linear model suffers from serial correlation and heteroscedasticity, the PCSE is adopted. This approach is robust to errors that show panel heteroscedasticity and contemporaneous correlation, alone or in group, see Becks and Katz [38]. The approach is suggested to perform well even in situations of extremely high heteroscedasticity and correlation of the errors (ibid).

In order to carry out an estimate of the threshold level of external debt for the panel of ECOWAS countries, equation (1) is transformed into a non-linear model as presented in equation (2);

$$
\begin{array}{r}
\operatorname{RealGDP}_{i t}=\alpha_{0}+\alpha_{1} E D_{i t}+\alpha_{1,1} E_{D S Q_{i t}}+\alpha_{2} O p n_{i t}+ \\
\alpha_{3} \operatorname{Inf}_{i t}+\alpha_{4} \operatorname{CoC}_{i t}+\alpha_{5} P S_{i t}+v_{i t}
\end{array}
$$

Where $E D S Q$ is External Debt squared. The study assumes the existence of non-linear impact of external debt on economic growth. Therefore, it is expected that at low levels of external debt, an increase in the proportion of external debt could promote growth, hence, $\alpha_{1}>0$. However, at higher levels or the doubling of external debt above certain 
levels could lead to a decline in growth, $\alpha_{1,1}<0$.

The series data were sourced mainly from the World Bank databank and UNCTAD statistics (see Table 5).

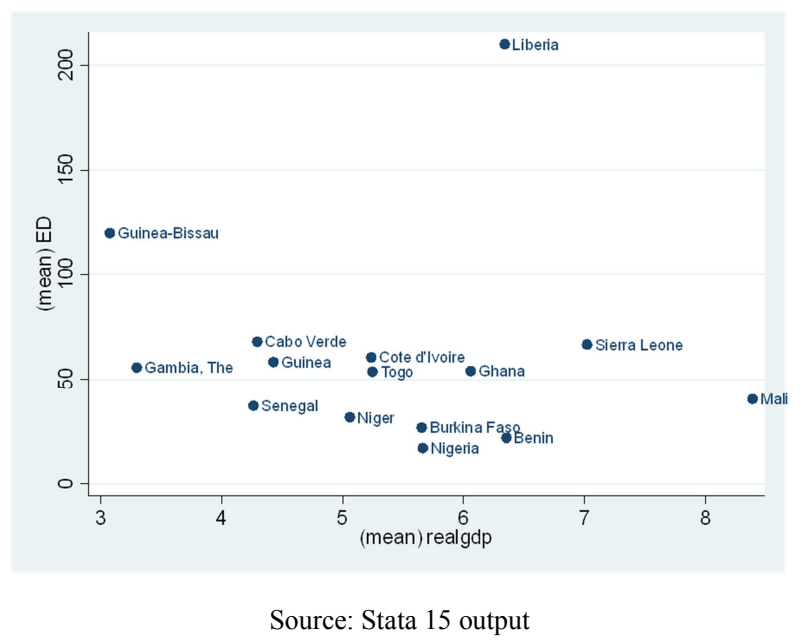

Figure 2. The Mean Value of Real GDP and External Debt.

\section{Presentation and Discussion of Results}

The study proceeds with a presentation of a scattered plot diagram, which offers an insight on the possible relationship between real GDP and external debt. As shown in Figure 2, it is observed that, in general, the relationship is negative between real GDP and external debt, suggesting that the higher the external debt of a country the lower the real GDP growth. However, in the case of Liberia, it was observed that, on average, the highest external debt value, corresponds to a real GDP of around $6.5 \%$, reflecting a better performance relative to most countries with low external debt.

Furtherance to the above, there was a check for CrossSection Dependence (CSD) and series stationarity test since they are underlying issues in panel data with large time dimension. Besides, testing for CSD in regional studies, where countries are highly interconnected, is imperative. Ignoring these issues could leave an analysis open to the possibility of being inaccurate see Pesaran [39].

\subsection{Cross Section Dependence (CSD) Test}

While other CSD tests exists such as the Langrange Multiplier test and Langrange Multiplier adjusted test, the Pesaran [ibid] CSD test is utilized in this study. The test is based on an average pair-wise correlation coefficient of the ordinary least square residuals from individual regressions in the panel. It can be applied to both balanced and unbalance panel data, and it is robust to structural breaks in the slope coefficients and error variances.

The CSD test was conducted for Model 1 (linear) and Model 2 (non-linear). The results are presented in Table 1. From the results, the study failed to reject the null hypothesis of cross-section independence in both models.

Table 1. Results of Cross-Sectional Dependence Test.

\begin{tabular}{lll}
\hline & Pesaran's test of cross section independence & p-value \\
\hline Model 1 & 0.385 & 0.6999 \\
Model 2 & 1.139 & 0.255 \\
\hline
\end{tabular}

Source: Authors computation using output from Stata 15.

\subsection{Panel Unit Root Test}

To account for series stationarity in the panel, the study relied on the Im-Pesaran-Shin (IPS) unit root test. The test performs well in dynamic heterogeneous panels, see Im et al. [40] and allows for serial correlation in residuals and heterogeneity dynamics and error variances across groups.
The IPS unit root test results are presented in Table 2. The series were found to be stationary at either level or after first difference at the $1 \%$ significance level. At level, Real GDP (Realgdp) and Inflation (Inf) were found to be stationary, while, External Debt (ED), Trade Openness (Opn), Control of Corruption (CoC) and Political Stability (PS) were stationary after first difference.

Table 2. Results of Im-Pesaran-Shin Panel Unit Root Test.

\begin{tabular}{llll}
\hline Variable & Level & First Difference & Integration Order \\
\hline Realgdp & $-4.157 * * *$ & & $\mathrm{I}(0)$ \\
ED & 0.196 & $-5.328^{* * *}$ & $\mathrm{I}(1)$ \\
Opn & -1.093 & $-6.036 * * *$ & $\mathrm{I}(1)$ \\
Inf & $-5.402 * * *$ & & $\mathrm{I}(0)$ \\
CoC & -1.063 & $-6.680 * * *$ & $\mathrm{I}(1)$ \\
PS & & $-10.329 * * *$ & $\mathrm{I}(1)$ \\
\hline
\end{tabular}

$* * * \mathrm{p}<1$

Source: Authors computation

\subsection{Estimation Results}

Estimation results for the two models: Model 1 (linear) and Model 2 (non-linear) are presented in Tables 3 and 4 respectively. While several estimation results are presented, only the PCSE (for the linear model) and FEM (for the nonlinear model) results, which are robust to heteroscedasticity 
(by using the robust standard errors), are used for analysis in Tables 3 and 4, respectively. However, it must be noted that the results of the POLS and REM are consistent with those of the PCSE and FEM for both models, respectively. We proceed with the presentation and discussion of the results as follows:

\subsubsection{Linear Model Estimation Result}

In Table 3, four estimation results are presented. The Hausman test statistics result indicated that the REM was more appropriate than the FEM as it fails to reject the null of the REM being appropriate. This suggests that the countryspecific unobserved effect is not correlated with the explanatory variables. Thereafter, the Breusch and Pagan Langrange Multiplier (BPLM) test was used to decide between the REM and the POLS. The BPLM result revealed that the POLS is more appropriate as there is no panel unobserved effect. Therefore, the study failed to reject the null of zero variances across entities. However, using the Wooldridge test for autocorrelation (see Table 7), it was observed that the POLS model suffers from serial correlation. Against this backdrop, the study resorted to the PCSE which is robust to autocorrelation and heteroscedasticity, hence, being used for the analysis. As alluded to earlier, results from the FEM, REM and POLS are consistent with the results of the PCSE for the linear model.

From the PCSE results, External debt (ED), Openness to trade $(\mathrm{Opn})$ and Control of Corruption $(\mathrm{CoC})$ were found to be significant at the conventional level of significance. On the contrary, Inflation (Inf) and Political Stability (PS) were found to be statistically insignificant. With the exception of $\mathrm{CoC}$, all the variables carried their expected signs.

The result reveals that a one percentage increase in external debt would lead to a decline in real GDP by $0.03 \%$, with a statistically significant coefficient at the $1 \%$ significance level. The result indicates that an increase in external debt is harmful to growth in the ECOWAS. Conventionally, in the loanable funds market, the interest rate increases as government debt accumulates. The increase in the rate of interest could demotivate investors from investing in a country. As such, the surge in external debt would crowd-out both domestic and foreign investment and this will, inevitably, harm national economic growth. The finding from the study is consistent with the works of Shahor [12] and De Vita et al. [13].

Differently, the more economically open the ECOWAS countries become, the higher the real GDP. The result shows that a one percentage increase in trade openness would increase real GDP growth by $0.07 \%$ annually in the region. The result purports that greater openness to trade could stimulate growth, given that, as countries become more open, it offers them the opportunity to benefit from the use of more advanced technologies, as well as, the transfer of improved skills thus, leading to a more rapid growth. The result bodes well with the findings by Keho [41].

Table 3. Results of Linear Model Estimations.

\begin{tabular}{|c|c|c|c|c|}
\hline & FEM & REM & POLS & PCSE \\
\hline ED & $-.0165 * * *(.0049)$ & $-.0198 * * *(.0045)$ & $-.0206 * * *(.0044)$ & $-.0264 * * *(.0095)$ \\
\hline Opn & $.0724 * * *(.0132)$ & $.0589 * * *(.0109)$ & $.0528 * * *(.0099)$ & $.0709 * * *(.0212)$ \\
\hline Inf & $-.1553 * *(.07)$ & $-.1051 *(.0555)$ & $-.0787(.0480)$ & $-.0640(.0603)$ \\
\hline $\mathrm{CoC}$ & $.6584(.8482)$ & $-.4177(.4657)$ & $-.4809(.3776)$ & $-.7062 *(0.4055)$ \\
\hline PS & $.1612(.3377)$ & $-.0318(.268)$ & $-.0541(.2336)$ & $.0093(.2796)$ \\
\hline _cons & $-.8024(3.4389)$ & $4.8668 * * *(1.678)$ & $5.5039 * * *(1.2669)$ & $5.1448 * * *(1.3610)$ \\
\hline Obs. & 300 & 300 & 300 & 300 \\
\hline Bruesch and Pagan LM Test & Prob $>$ Chibar $2=0.1000$ & & & \\
\hline
\end{tabular}

Standard errors in parenthesis

$* * * \mathrm{p}<.01, * * \mathrm{p}<.05, * \mathrm{p}<.1$

Source: Authors computation

Furthermore, the control of corruption $(\mathrm{CoC})$ was found to affect growth in the ECOWAS region negatively, with a significant coefficient. The finding shows that a unit increase in $\mathrm{CoC}$ would reduce economic growth by $70 \%$ annually. The result goes against the study's expectation. However, the result supports the findings of Ahmad et al. [42] and Ighodaro and Igbinedion [43]. From a theoretical stand point, if the control of corruption is not accompanied by other structural improvements like the reduction in rigid bureaucratic structures, unnecessary delays that could discourage investors could be created thus, slowing down growth.

\subsubsection{Non-Linear Model Estimation Results}

The results of the non-linear model (threshold model), as presented in Table 4, reveals that, the FEM was the most appropriate for analysis based on the Hausman test statistics which shows that the unobserved country effect is correlated with the explanatory variables. This conclusion was further strengthened after the BPLM test reveals that there is a panel unobserved effect, thus, rejecting the POLS as an appropriate estimator. From the result, the threshold condition $\left(\alpha_{1}>\right.$ 0 and $\alpha_{1,1}<0$ ) was met and the coefficient were found to be statistically significant. The Wooldridge test for autocorrelation (see Table 7) confirms that, there is no evidence of autocorrelation. The findings from the non-linear estimation are relatively consistent with the results of the static model. The coefficient of openness is positive and statistically significant, indicating that openness of the ECOWAS region will promote growth. The result also shows that in line with general expectation, inflation was found to 
affect growth negatively, with a statistically significant coefficient. Higher level of inflation creates macroeconomic instability and this could affect the confidence of investors negatively. The result indicates that a one percentage point increases in inflation would reduce real GDP by $0.2 \%$.

Table 4. Results of Non-Linear model Estimation.

\begin{tabular}{llll}
\hline & FEM & REM & POLS \\
\hline ED & $.0222^{* *}(.0112)$ & $.0091(.0104)$ & $.0003(.0100)$ \\
EDSQ & $-.0001^{* * *(.0002)}$ & $-.0001^{* * *(.0002)}$ & $-.0001 * *(.0002)$ \\
Open & $.0753^{* * *(.0129)}$ & $.0618^{* * *(.0108)}$ & $.0552^{* * *(.0098)}$ \\
Inf & $-.1994 * * *(.0694)$ & $-.1221^{* *}(.0547)$ & $-.0867 *(.0478)$ \\
COC & $.0206(.8452)$ & $-.5177(.4563)$ & $-.5008(.3748)$ \\
PS & $.0934(.3303)$ & $-.115(.2642)$ & $4.3718^{* * *(1.6445)}$ \\
cons & $.4529(3.3749)$ & 300 & $3.9683 * * *(1.2782)$ \\
Obs. & 300 & & 300 \\
Hausman Test & Prob $>$ Chi2 $=0.0199$ & \\
Breusch and Pagan LM Test & Prob $>$ Chibar2=0.0076 & \\
\hline
\end{tabular}

Standard errors are in parentheses

$* * * \mathrm{p}<.01, * * \mathrm{p}<.05, * \mathrm{p}<.1$

Source: Authors computation

Furthermore, the result suggests that initially external debt (ED) can promote economic growth but the doubling of external debt, represented by external debt squared (EDSQ), would eventually translate into a negative effect and hurt economic growth in the ECOWAS countries. This is evident in positive and negative coefficients for ED and EDSQ respectively. Having met the pre-conditions, the threshold level is determined by taking the derivative of real GDP with respect to ED and EDSQ and set to zero as follows;

$$
\begin{gathered}
\frac{\partial r e a l G D P}{\partial E D}=0.0222-2(0.0001) E D=0 \\
\Rightarrow 0.0222=0.0002 E D \\
\Rightarrow E D=\frac{0.0222}{0.0002}=111 \%
\end{gathered}
$$

As shown in equation (3), the threshold level of external debt in the ECOWAS region is $111 \%$. The study identifies a nonlinear relationship between external debt and real GDP. This shows the optimal level of external debt, and serves as the turning point, beyond which debt will negatively affect growth. The implication of this finding is that, ECOWAS countries could have their external debt as high as $111 \%$ and economic growth will not be hurt but any debt exceeding this level would affect growth negatively. Nonetheless, the results show that any increase in external debt above $111 \%$ will reduce growth in the ECOWAS region by $0.0001 \%$ while below the threshold level economic growth will improve by $0.0222 \%$

\section{Conclusion}

The main objective of the study was to investigate the impact of external debt on economic growth in the ECOWAS Member States, and also determine the threshold level of external debt conducive for growth. The study utilized panel data from 2000 to 2019 and employed four estimation techniques including the Pooled Ordinary Least Squares
(POLS), Fixed Effect Model (FEM), Random Effect Model (REM) and Panel Corrected Standard Errors (PCSE) techniques. The study specified two models, viz; linear and non-linear models. The stationarity test based on the ImxPesaran-Shin (IPS) unit root test, found a mixture of I(0) and I(1) variables. Results from the linear model revealed that the major determinants of economic growth in the ECOWAS countries during the study period, were external debt (ED), Openness to trade (Opn) and Control of Corruption ( $\mathrm{CoC})$. The study reveals a positive relationship between openness and growth, whilst both external debt and control of corruption were found to have a negative effect on growth. Furthermore, results from the non-linear model collaborate well with the linear results. Specifically, the non-linear result showed that openness had a positive impact on growth. However, the result found an inverse relationship between inflation and growth. The study established a nonlinear relationship between external debt and real GDP, and confirmed that the optimal threshold level of external debt in the ECOWAs countries is $111 \%$. Intuitively, the result showed that any increase in external debt above $111 \%$ will reduce growth in the ECOWAS region by $0.0001 \%$ while below the threshold level, economic growth will improve by $0.0222 \%$. A key policy implication of the study is that, governments of the ECOWAS countries should ensure that, external debt are utilized in growth enhancing sectors, with a view to boost growth. Also, governments should develop debt management strategic policies, with a view to keep debt levels within sustainable limits. Furthermore, there is a need for governments to seek alternative sources of funding for financing of basic infrastructure. This can be achieved through an increase in domestic resource mobilization drive. Also, governments should put in place mechanisms to reduce corruption or eradicate corrupt practices, through name and shame of corrupt officials, strengthen the judiciary and anticorruption offices. 


\section{Appendix}

Table 5. Definition and Sources of Variables

\begin{tabular}{lll}
\hline Variable & Definition & Source \\
\hline RealGDP & Annual average growth rates of gross domestic product (GDP). & UNCTAD (2021) \\
ED & Total external debt stocks as a percentage of gross national income. & WDI (2021) \\
Opn & $\begin{array}{l}\text { Sum of import and export as a percentage of GDP } \\
\text { Inf }\end{array}$ & $\begin{array}{l}\text { Consumer price indices (CPI) as annual growth rate indicator. } \\
\text { Control of Corruption captures perceptions of the extent to which public power is exercised for private gain, }\end{array}$ \\
CoC & $\begin{array}{l}\text { including both petty and grand forms of corruption, as well as capture" of the state by elites and private interests. It } \\
\text { is measured on a scale of -2.5 (most corrupt) to 2.5 (least corrupt) }\end{array}$ & WGI (2021) \\
PS & $\begin{array}{l}\text { Political Stability measures perceptions of the likelihood of political instability and/or politically-motivated } \\
\text { violence, including terrorism. It is measured on a scale of }-2.5 \text { (most unsatble) to 2.5 (least unstable) }\end{array}$ & WGI (2021) \\
\hline
\end{tabular}

**Note: For ease of interpretation, $\mathrm{CoC}$ and PS were rescaled from -2.5 to 2.5 to 0 (Worst) to 10 (best) using the following formula: $\mathrm{x}=(\mathrm{a}+2.5) \times 2$. Where' $\mathrm{x}$ ' represent new rescale value and ' $\mathrm{a}$ ' is the original scale value.

Table 6 List of ECOWAS Countries

ECOWAS Member States
Benin, Burkina Faso, Cabo Verde, Cote d'Ivoire, The Gambia, Ghana, Guinea, Guinea-Bissau, Liberia, Mali, Niger, Nigeria, Senegal, Sierra Leone, and
Togo.

Table 7 Results of Wooldridge Test for Autocorrelation

\begin{tabular}{ll}
\hline \multicolumn{2}{l}{ Wooldridge Test for Autocorrelation in Panel data } \\
\hline & F statistic \\
\hline Model 1 & $4.965^{* * *}$ \\
Model 2 & 3.743 \\
\hline
\end{tabular}

H0: no first order serial correlation

$* * * \mathrm{p}<0.05$

\section{References}

[1] Reinhart, C. M., Reinhart, V. R., \& Rogoff, K. S. (2012). Public debt overhangs: advanced-economy episodes since 1800. Journal of Economic Perspectives, 26 (3), 69-86.

[2] Eaton, J. (1993). Sovereign debt: A primer. The World Bank Economic Review, 7 (2), 137-172.

[3] Panizza, U., Sturzenegger, F., \& Zettelmeyer, J. (2010, June). International government debt. United Nations Conference on Trade and Development. https://unctad.org/system/files/official-

document/osgdp20103_en.pdf. Access September, 2021.

[4] Krugman, P. (1988). Financing vs. forgiving a debt overhang. Journal of development Economics, 29 (3), 253-268.

[5] Pattillo, C., Poirson, H., Ricci, L., Kraay, A., \& Rigobon, R. (2003, January). Through what channels does external debt affect growth? [with Comments and Discussion]. In Brookings Trade Forum (pp. 229-277). Brookings Institution Press.

[6] Jayaraman, T. K., \& Lau, E. (2009). Does external debt lead to economic growth in Pacific island countries. Journal of Policy Modeling, 31 (2), 272-288.

[7] Butts, H. C. (2009). Short term external debt and economic growth-Granger causality: Evidence from Latin America and the Caribbean. The Review of Black political economy, 36 (2), 93-111.

[8] Frimpong, J. M., \& Oteng-Abayie, E. F. (2006). The impact of external debt on economic growth in Ghana: a cointegration analysis. Journal of Science and Technology (Ghana), 26 (3),
$122-131$.

[9] Serieux, J., \& Samy, Y. (2001, August). The debt service burden and growth: Evidence from low income countries. In WIDER Conference on Debt Relief (pp. 17-18).

[10] Warner, A. M. (1992). Did the debt crisis cause the investment crisis?. The quarterly journal of economics, 107 (4), 1161-1186.

[11] Baum, A., Checherita-Westphal, C., \& Rother, P. (2013). Debt and growth: New evidence for the euro area. Journal of international money and finance, 32, 809-821.

[12] Shahor, T. (2018). The impact of public debt on economic growth in the Israeli economy. Israel Affairs, 24 (2), 254-264.

[13] De Vita, G., Trachanas, E., \& Luo, Y. (2018). Revisiting the bi-directional causality between debt and growth: Evidence from linear and nonlinear tests. Journal of International Money and Finance, 83, 55-74.

[14] Geiger, L. T. (1990). Debt and economic development in Latin America. The Journal of Developing Areas, 24 (2), 181-194.

[15] Cordella, T., Ricci, L. A., \& Ruiz-Arranz, M. (2005). Debt Overhang or Debt Irrelevance? Revisiting the Debt-growth Link. Vol 2005, Issue 223. https://doi.org/10.5089/9781451862423.001. Access August, 2021.

[16] Deshpande, A. (1997). The debt overhang and the disincentive to invest. Journal of development Economics, 52 (1), 169-187.

[17] Chowdhury, K. (1994). A structural analysis of external debt and economic growth: some evidence from selected countries in Asia and the Pacific. Applied Economics, 26 (12), 11211131. 
[18] Afxentiou, P. C., \& Serletis, A. (1996). Growth and foreign indebtedness in developing countries: an empirical study using long-term cross-country data. The Journal of developing areas, $31(1), 25-40$

[19] Cohen, D. (1993). Low Investment and Large LDC Debt in the 1980's. The American Economic Review, 437-449.

[20] Minea, A., \& Parent, A. (2012). Is high public debt always harmful to economic growth? Reinhart and Rogoff and some complex nonlinearities. https://halshs.archivesouvertes.fr/halshs-00700471/document. Access August, 2021.

[21] Jarju, I., Nyarko, E., Adams, K., Haffner, O., \& Odeniran, O. S. (2016). The relationship between external debt and economic growth in the West African Monetary Zone: A panel data analysis. WAMI Occasional Paper Series NO. 12. https://econpapers.repec.org > RePEc: wam: wpaper: 12. Access August 2021.

[22] Amoateng, K., \& Amoako-Adu, B. (1996). Economic growth, export and external debt causality: The case of African countries. Applied Economics, 28 (1), 21-27.

[23] Senadza, B., Fiagbe, K., \& Quartey, P. (2017). The effect of external debt on economic growth in Sub-Saharan Africa. International Journal of Business and Economic Sciences Applied Research (IJBESAR), 11 (1).

[24] Fosu, A. K. (1999). The external debt burden and economic growth in the 1980s: evidence from sub-Saharan Africa. Canadian Journal of Development Studies/Revue canadienne d'études du développement, 20 (2), 307-318.

[25] Iyoha, M. A. (1999). "External Debt and Economic Growth in Sub-Saharan African Countries: An Econometric Study." AERC Research Paper 90, Nairobi Kenya.

[26] Cunningham, R. T. (1993). The effects of debt burden on economic growth in heavily indebted developing nations. Journal of economic development, 18 (1), 115-126.

[27] Ezeabasili, V. N., Isu, H. O., \& Mojekwu, J. N. (2011). Nigeria's external debt and economic growth: An error correction approach. International Journal of Business and Management, 6 (5), 156-170.

[28] Ogunmuyiwa, M. S. (2011). Does external debt promote economic growth in Nigeria? Current research journal of economic theory, 3 (1), 29-35.

[29] Ajayi, L. B., \& Oke, M. O. (2012). Effect of external debt on economic growth and development of Nigeria. International journal of business and social science, 3 (12), 297-304.

[30] Karagöl, E. (2012). The causality analysis of external debt service and GNP: The case of Turkey. Central Bank Review, 2 (1), 39-64.

[31] Were, M. (2001). The impact of external debt on economic growth in Kenya: An empirical assessment, UNU-WIDER, Research Paper, No. DP2001/116. http://www.rrojasdatabank.info/unudp01/dp2001-116_1.pdf. Access September 2021.

[32] Malik, S. Hayat, M. K, and Hayat, M. U. (2010). External Debt and Economic Growth: Empirical Evidence from Pakistan. International Research Journal of Finance and Economics. ISSN 1450-2887 Issue 44.

[33] N'Zue, F. F. (2020). Is External Debt Hampering Growth in the ECOWAS Region. International Journal of Economics and Finance, 12 (4), 54-66.

[34] Elbadawi, I., Ndulu, B. J., \& Ndung'u, N. (1997). Debt overhang and economic growth in Sub-Saharan Africa. External finance for low-income countries, 49-76.

[35] Medina, J. V., Medina, G. V., and Pérez, O. M. (2020). The impact of public debt on economic growth: An empirical study of Mexico (1994-2016). CEPAL Review N 130, April.

[36] Topal, P. (2014). Threshold effects of public debt on economic growth in the euro area economies. Available at SSRN 2421147.

[37] Ahlborn, M., \& Schweickert, R. (2018). Public debt and economic growth-economic systems matter. International Economics and Economic Policy, 15 (2), 373-403.

[38] Beck, N., \& Katz, J. N. (1995). What to do (and not to do) with time-series cross-section data. American political science review, 89 (3), 634-647.

[39] Peseran, H. (2004). General Diagnostic Tests for Cross Section Dependence in Panels, University of Cambridge and IZA Bonn. Discussion paper No. 1240.

[40] Im, K. S., Pesaran, M. H., \& Shin, Y. (2003). Testing for unit roots in heterogeneous panels. Journal of econometrics, 115 (1), 53-74.

[41] Keho, Y. (2017). The impact of trade openness on economic growth: The case of Cote d'Ivoire. Cogent Economics \& Finance, 5 (1), 1332820.

[42] Ahmad, E., Ullah, M. A., \& Arfeen, M. I. (2012). Does corruption affect economic growth? Latin American journal of economics, 49 (2), 277-305.

[43] Ighodaro, C. A., \& Igbinedion, S. O. (2020). Corruption and Economic Growth in West Africa. JEJAK: Jurnal Ekonomi dan Kebijakan, 13 (2), 265-279. 